\title{
Front Matter: Volume 8113
}

, "Front Matter: Volume 8113," Proc. SPIE 8113, Linear and Nonlinear Optics of Organic Materials XI, 811301 (22 September 2011); doi: 10.1117/12.912642

Event: SPIE Photonic Devices + Applications, 2011, San Diego, California, SPIE. United States 


\title{
PROCEEDINGS OF SPIE
}

\section{Linear and Nonlinear Optics of Organic Materials XI}

\author{
Jean-Michel Nunzi \\ Rachel Jakubiak \\ Theodore G. Goodson III \\ Manfred Eich \\ Editors
}

21-22 August 2011

San Diego, California, United States

Sponsored and Published by

SPIE

Volume 8113 
The papers included in this volume were part of the technical conference cited on the cover and title page. Papers were selected and subject to review by the editors and conference program committee. Some conference presentations may not be available for publication. The papers published in these proceedings reflect the work and thoughts of the authors and are published herein as submitted. The publisher is not responsible for the validity of the information or for any outcomes resulting from reliance thereon.

Please use the following format to cite material from this book:

Author(s), "Title of Paper," in Linear and Nonlinear Optics of Organic Materials XI, edited by Jean-Michel Nunzi, Rachel Jakubiak, Theodore G. Goodson III, Manfred Eich, Proceedings of SPIE Vol. 8113 (SPIE, Bellingham, WA, 2011) Article CID Number.

ISSN 0277-786X

ISBN 9780819487230

Published by

SPIE

P.O. Box 10, Bellingham, Washington 98227-0010 USA

Telephone +1 3606763290 (Pacific Time) · Fax +1 3606471445

SPIE.org

Copyright (C) 2011, Society of Photo-Optical Instrumentation Engineers

Copying of material in this book for internal or personal use, or for the internal or personal use of specific clients, beyond the fair use provisions granted by the U.S. Copyright Law is authorized by SPIE subject to payment of copying fees. The Transactional Reporting Service base fee for this volume is $\$ 18.00$ per article (or portion thereof), which should be paid directly to the Copyright Clearance Center (CCC), 222 Rosewood Drive, Danvers, MA 01923. Payment may also be made electronically through CCC Online at copyright.com. Other copying for republication, resale, advertising or promotion, or any form of systematic or multiple reproduction of any material in this book is prohibited except with permission in writing from the publisher. The CCC fee code is 0277-786X/11/ \$18.00.

Printed in the United States of America.

Publication of record for individual papers is online in the SPIE Digital Library.

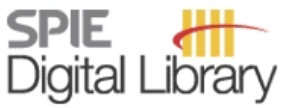

SPIEDigitalLibrary.org

Paper Numbering: Proceedings of SPIE follow an e-First publication model, with papers published first online and then in print and on CD-ROM. Papers are published as they are submitted and meet publication criteria. A unique, consistent, permanent citation identifier (CID) number is assigned to each article at the time of the first publication. Utilization of CIDs allows articles to be fully citable as soon as they are published online, and connects the same identifier to all online, print, and electronic versions of the publication. SPIE uses a six-digit CID article numbering system in which:

- The first four digits correspond to the SPIE volume number.

- The last two digits indicate publication order within the volume using a Base 36 numbering system employing both numerals and letters. These two-number sets start with $00,01,02,03,04$, $05,06,07,08,09,0 A, 0 B \ldots 0 Z$, followed by 10-1Z, 20-2Z, etc.

The CID number appears on each page of the manuscript. The complete citation is used on the first page, and an abbreviated version on subsequent pages. Numbers in the index correspond to the last two digits of the six-digit CID number. 


\section{Contents}

vii Conference Committee

BEAM HANDLING DEVICES

811302 Recent advances in photorefractive polymers (Invited Paper) [8113-01]

J. Thomas, College of Optics and Photonics, Univ. of Central Florida (United States) and Univ. of Central Florida (United States); C. W. Christenson, B. Lynn, P.-A. Blanche, R. Voorakaranam, R. A. Norwood, College of Optical Sciences, The Univ. of Arizona (United States); M. Yamamoto, Nitto Denko Technical Corp. (United States); N. Peyghambarian, College of Optical Sciences, The Univ. of Arizona (United States)

811303 Thermally stable hybrid organic/inorganic resonant cavities [8113-02]

H. S. Choi, A. M. Armani, The Univ. of Southern California (United States)

PLASMONICS, FABRICATION, AND PROPERTIES

811309 Nonlinear photochemistry and 3D microfabrication with Q-switched Nd:YAG microchip lasers (Invited Paper) [8113-08]

P. L. Baldeck, T. Scheul, M. Bouriau, O. Stephan, Lab. Interdisciplinaire de Physique, CNRS, Univ. Grenoble 1 (France); J.-P. Malval, Institut de Sciences des Matériaux de Mulhouse, CNRS, Univ. Haute Alsace (France); C.-L. Lin, Central Taiwan Univ. of Science and Technology (Taiwan); C.-T. Lin, C.-L. Tseng, C. Huang, T.-T. Chung, National Taiwan Univ. (Taiwan)

$8113 \mathrm{OB} \quad$ Realizing metal and quantum dot containing patterns by two-photon lithography [8113-10] P. Prabhakaran, Hannam Univ. (Korea, Republic of); Y. Son, KAIST (Korea, Republic of); K. K. Jang, Hannam Univ. (Korea, Republic of); D.-Y. Yang, KAIST (Korea, Republic of); K.-S. Lee, Hannam Univ. (Korea, Republic of)

$81130 \mathrm{C}$ Metal plasmon enhanced luminescence of rhodamine B [8113-11]

F. Liu, B. S. Rao, G. Aldea, J.-M. Nunzi, Queen's Univ. (Canada)

NEW CONCEPTS FOR SECOND-ORDER EFFECTS

$81130 \mathrm{OE}$ Measurement of stress and strain applied to electrochemically aligned collagen fibres by second-harmonic generation microscopy [81 13-13]

N. Goami, K. Yoshiki, T. Namazu, S. Inove, Univ. of Hyogo (Japan)

8113 OF Spontaneous chirality in an octupolar discotic crystal [8113-14]

S. Van Cleuvenbergen, M. A. Van der Veen, I. Asselberghs, Katholieke Univ. Leuven (Belgium); G. Hennrich, Univ. Autónoma de Madrid (Spain); T. Verbiest, K. Clays, Katholieke Univ. Leuven (Belgium) 
811306 Optimizing the second-order nonlinear optical response in some indoline-based chromophores at the molecular and macroscopic levels [8113-15]

A. Teshome, Katholieke Univ. Leuven (Belgium); M. D. H. Bhuiyan, M. Ashraf, G. J. Gainsford, A. J. Kay, Industrial Research Ltd. (New Zealand); S. Van Cleuvenbergen, I. Asselberghs,

K. Clays, Katholieke Univ. Leuven (Belgium)

$8113 \mathrm{OH} \quad$ Nonreciprocal silicon-organic nanophotonic structures [8113-16]

D. Jalas, A. Stepan, A. Petrov, Hamburg Univ. of Technology (Germany); T. Verbiest,

G. Koeckelberghs, Katholieke Univ. Leuven (Belgium); M. Eich, Hamburg Univ. of Technology

(Germany)

\section{FUNDAMENTAL PROPERTIES}

$81130 \mathrm{~J}$ Optical nonlinearity and power limiting in organic molecules and nanocomposites (Invited Paper) [8113-18]

R. Philip, Raman Research Institute (India); J. Thomas, CREOL, The College of Optics and Photonics, Univ. of Central Florida (United States) and Univ. of Central Florida (United States)

$81130 \mathrm{~K}$ Assessing limitations to the two-level approximation in nonlinear optics for organic chromophores by ab initio methods [8113-19]

M. M. Coles, J. N. Peck, V. S. Oganesyan, D. L. Andrews, Univ. of East Anglia Norwich (United Kingdom)

$8113 \mathrm{OL}$ Why do we need three levels to understand the molecular optical response? [8113-20] J. Perez-Moreno, Katholieke Univ. Leuven (Belgium); K. Clays, Katholieke Univ. Leuven (Belgium) and Washington State Univ. (United States); M. G. Kuzyk, Washington State Univ. (United States)

$81130 \mathrm{M}$ Minimizing the quantum-confinement effects on nonlinear optical properties of quantum wires [8113-21]

S. Shafei, M. G. Kuzyk, Washington State Univ. (United States)

\section{MULTI-PHOTON EFFECTS}

$81130 \mathrm{~N}$ Single-, two-, and multi-photon driven molecular motion and nanopatterning in azo-polymer films (Keynote Paper) [8113-22]

Z. Sekkat, Moroccan Foundation for Advanced Science, Innovation and Research (Morocco), Univ. of Rabat (Morocco), Hassan II Academy of Science and Technology (Morocco), RIKEN (Japan), and Osaka Univ. (Japan); H. Ishitobi, M. Tanabe, T. Hiramatsu, Osaka Univ. (Japan); S. Kawata, RIKEN (Japan) and Osaka Univ. (Japan)

8113 OP Linkage effects to nonlinear optical properties of porphyrin-appended mixed (porphyrinato)(phthalocyaninato) yttrium(III) double-decker complexes [8113-24] Y. Li, South Dakota State Univ. (United States); X. Zhang, Univ. of Science and Technology Beijing (China); X. Yan, South Dakota State Univ. (United States); Y. Bian, J. Jiang, Univ. of Science and Technology Beijing (China) 
$81130 Q \quad$ Towards Monte Carlo simulation of the photomechanical effect in polymeric fibers (Invited Paper) [81 13-25]

G. Pawlik, P. Wrobel, A. C. Mitus, Wroclaw Univ. of Technology (Poland); M. G. Kuzyk, Washington State Univ. (United States)

8113 OS Photochromic polymers as a versatile tool for devices based on switchable absorption and other optical properties [8113-27]

C. Bertarelli, R. Castagna, Politecnico di Milano (Italy) and Instiuto Italiano di Tecnologia (Italy); G. Pariani, Politecnico di Milano (Italy) and INAF - Osservatorio Astronomico di Brera (Italy); A. Bianco, INAF - Osservatorio Astronomico di Brera (Italy)

\section{NONLINEAR OPTICAL EFFECTS}

$81130 \mathrm{~V}$ Modeling the hyperpolarizability dispersion with the Thomas-Kuhn sum rules [8113-30] K. De Mey, J. Perez-Moreno, Katholieke Univ. Leuven (Belgium); K. Clays, Katholieke Univ. Leuven (Belgium) and Washington State Univ. (United States)

$81130 \mathrm{~W}$ Investigation of nonlinear optical properties of protonated mixed (porphyrinato)(phthalocyaninato) rare-earth(III) double-decker complexes by Z-scan technique [8113-31]

Y. Li, M. Yan, M. Jiang, X. Yan, South Dakota State Univ. (United States); Y. Bian, J. Jiang, Univ. of Science and Technology Beijing (China)

$81130 X$ Multi-wavelength top-hat nanosecond $Z$ scans to determine excited-state absorption cross sections of a platinum bipyridyl complex in the visible [8113-32]

W. Shensky III, T. M. Pritchett, M. J. Ferry, U.S. Army Research Lab. (United States); R. Liu, Z. Li, W. Sun, North Dakota State Univ. (United States)

\section{POSTER SESSION}

$81130 Z$ Synthesis and nonlinear optical properties of novel N,N-dihydroxyethyl-based molecular organic glasses using triaryl substitutes as amorphous phase formation enhancers [81 13-35] K. Traskovskis, Riga Technical Univ. (Latvia); I. Mihailovs, Riga Technical Univ. (Latvia) and Univ. of Latvia (Latvia); A. Tokmakovs, Univ. of Latvia (Latvia); V. Kokars, V. Kampars, Riga Technical Univ. (Latvia); M. Rutkis, Univ. of Latvia (Latvia)

811310 Time-resolved optical writing on a photosensitive and fluorescent polymer film [8113-36] Z. Pan, R. Akrobetu, Fisk Univ. (United States); J. Lott, C. Ryan, A. Saini, J. Shan, Case Western Reserve Univ. (United States); R. Mu, Fisk Univ. (United States); K. D. Singer, Case Western Reserve Univ. (United States); C. Weder, Univ. of Fribourg (Switzerland); S. H. Morgan, Fisk Univ. (United States)

811315 Synthesis of the novel $\beta$-cyclodextrin-chromophore inclusion compound and research on the electro-optic activity of its systems [8113-41]

S. Bo, Z. Chen, Z. Zhen, X. Liu, Technical Institute of Physics and Chemistry (China)

Author Index 
Downloaded From: https://www.spiedigitallibrary.org/conference-proceedings-of-spie on 26 Apr 2023

Terms of Use: https://www.spiedigitallibrary.org/terms-of-use 


\title{
Conference Committee
}

\author{
Symposium Chair
}

Zakya H. Kafafi, National Science Foundation (United States)

Conference Chair

Jean-Michel Nunzi, Queen's University (Canada)

Conference Cochairs

Rachel Jakubiak, Air Force Research Laboratory (United States)

Theodore G. Goodson III, University of Michigan (United States)

Manfred Eich, Technische Universität Hamburg-Harburg (Germany)

Program Committee

Kevin D. Belfield, University of Central Florida (United States)

Antao Chen, University of Washington (United States)

Koen Clays, Katholieke Universiteit Leuven (Belgium)

Alain F. Fort, Institut de Physique et Chimie des Matériaux de Strasbourg (France)

François Kajzar, Université d'Angers (France)

Satoshi Kawata, Osaka University (Japan)

Mark G. Kuzyk, Washington State University (United States)

Charles Y. C. Lee, Air Force Office of Scientific Research (United States)

Kwang-Sup Lee, Hannam University (Korea, Republic of)

Geoffrey A. Lindsay, Naval Air Warfare Center Aircraft Division (United States)

Aristides Marcano, Delaware State University (United States)

Robert A. Norwood, College of Optical Sciences, The University of Arizona (United States)

André P. Persoons, Katholieke Universiteit Leuven (Belgium)

Joy E. Rogers-Haley, Air Force Research Laboratory (United States)

Jayan Thomas, College of Optical Sciences, The University of Arizona (United States)

A. Todd Yeates, Air Force Research Laboratory (United States)

Session Chairs

1 Beam Handling Devices

Jean-Michel Nunzi, Queen's University (Canada) 
2 Nanomaterials for NLO

Jayan Thomas, College of Optical Sciences, The University of Arizona (United States)

3 Plasmonics, Fabrication, and Properties

Kwang-Sup Lee, Hannam University (Korea, Republic of)

4 New Concepts for Second-order Effects

Jayan Thomas, College of Optical Sciences, The University of Arizona (United States)

5 Fundamental Properties

Rachel Jakubiak, Air Force Research Laboratory (United States)

6 Multi-photon Effects

Manfred Eich, Technische Universität Hamburg-Harburg (Germany)

7 Photochromism

Zouheir Sekkat, Moroccan Foundation for Advanced Science, Innovation and Research (Morocco)

$8 \quad$ Nonlinear Optical Effects

Antoni C. Mitus, Wroclaw University of Technology (Poland) 